\title{
MJMR CHARACTERISTICS OF HYPERTENSIVE PATIENTS IN SUKABUMI REGENCY
}

\author{
Hendri Hadiyanto* \\ Nursing Lecturer, Muhammadiyah University Sukabumi \\ *Corresponding Author's Email: hadiyantohendri@yahoo.co.id
}

\begin{abstract}
Background: WHO (World Health Organization), through Global Data Status Report on Noncommunicable Disesases (2010) states that in 2025 there are projections of around 29 percent of the world's citizens suffering from hypertension, and 40 percent of hypertensive patients will be from developing countries. The risk of death due to high hypertension and complications are due to poor handling of hypertension. Quoting the results of Basic Health Research (Riskesdas, 2013), national prevalence for hypertension is $25.8 \%$, of which one-third were diagnosed or treated for medication and two-thirds were undiagnosed let alone taking medication. Objective: The purpose of this study is to find out the characteristics of hypertensive patients in Sukabumi Regency. Methods: The population included in the study are all hypertensive patients in Sukabumi regency covering 47 districts. Samples of hypertensive patients taken include 7 districts in Northern Sukabumi, Central Sukabumi and Southern Sukabumi. The technique of taking the sample used is Accidental Sampling technique. Result: The results of this study showed that hypertensive patients were mostly female and aged between 45 and 49 years. Hypertension sufferers mostly work as laborers. Hypertension sufferers have the habit of eating salted fish. Hypertension sufferers mostly have the habit of drinking coffee. Hypertension sufferers mostly do not have the habit of exercising every week. Hypertension sufferers mostly have a habit of smoking every day. Hypertension sufferers mostly have problematic emotional status. Conclusion: The research result shows the habit pattern of hypertension victims in Sukabumi Regency and points out that it is mainly caused by unhealthy lifestyle, especially food habits of the victims. Having fast foods, salty food and food containing preservatives and chemicals increases the chances of hypertension.
\end{abstract}

\section{Keywords: Characteristics of Hypertension Sufferers}

\section{INTRODUCTION}

Hypertension is often found in the community and a person usually does not realize that he has hypertension. Hypertension is diagnosed after conducting a medical check-up at a health service place. The cause of hypertension is descent, age, sex, obesity (overeating), less exercise, stress, and excessive salt consumption. Other influences: caffeine, smoking, alcohol consumption, some medicines etc. There are several risk factors that can cause hypertension. Individuals with a family history of hypertension have twice the bigger risk to suffer from hypertension than people who don't have family with history of hypertension. Obesity can cause blockage in blood vessels so it can increase blood pressure and a person experiencing stress can trigger an increase in blood pressure (Hall, Hildebrandt \& Kuo, 2001; Madrigal et al., 2011; Abate et al., 2001; Dobrian et al., 2000).

The number of Hypertension patients is increasing. WHO (World Health Organization) through Global Data Status Report on Noncommunicable Disesases (2010) states that in 2025 there are projections of around 29 percent of the world's citizens suffering from hypertension and 40 percent of hypertensive patients will be from developing countries. The risk of death increases due to high level of hypertension complications that's caused by poor handling of hypertension. Quoting the results of Basic Health Research (Riskesdas, 2013) national prevalence for hypertension is $25.8 \%$, one-third of which were 
diagnosed or treated for medication and two-thirds were undiagnosed, let alone taking medication.

Society in Indonesia and Asia is generally consuming high natron (salt) because they are used to consuming ketchup, seasoning MSG (Monosodiumglutamate) in a large quantity. The salt consumption average is between $30-40$ gram per day compared to Americans which is only 6-18 gram per day (Soenardi, 2000).

Majority of the people in Sukabumi regency are Sundanese, and in the habit of consuming food that contains salt with unknown salt concentration. The serving meal often serves salted fish and chili sauce particularly in countryside area. The habit of smoking is also very high in Sukabumi regency area among teenagers, adults, and advanced age. A previous study that was conducted by Sukabumi Regency Health Department stated that hypertension is increasing every year. From the data in 2014, the total number of affected population was 13,036 and in 2015 it dramatically increased to 31,034 people. The disease had even affected the age of $15-24$ in 2014 by as many as 180 people and in 2015 by as many as 488 people.Based on the previous research, the researcher found that the patients with hypertension in Sukabumi Regency who had knowledge about the effects of hypertension disease was $56.9 \%$, and the patients with hypertension who did not have knowledge about the effects of hypertension disease was $61.8 \%$. Based on the description above, the researcher wants to explain the characteristics of hypertensive patients in Sukabumi Regency.

\section{RESEARCH METHODOLOGY}

The population selected for this study covers 47 districts in Sukabumi regency and all are hypertensive patients. Samples of hypertensive patients taken included 7 districts that lived in Northern Sukabumi, Central Sukabumi and Southern Sukabumi. The technique of selecting the sample was Accidental Sampling technique.

\section{RESULTS AND DISCUSSION}

The hypertension victims in Sukabumi Regency in the range of 46 to 55 years were as many as $28.45 \%$. Based on sex, it is more men than women, as much as $56.9 \%$. Based on elementary school level, it is more than $51 \%$ and based on occupation, farmer is more than $35.3 \%$. Knowledge factor of hypertension care is very important in avoiding complications in hypertension disease, especially when it is caused by unhealthy lifestyle. Based on the research, hypertension victim in Sukabumi regency who has hypertension disease information is quite high, i.e. as many as $56.9 \%$ and who does not know the effect of hypertension disease are as many as $61.8 \%$.

Regarding the habit pattern of hypertension victim in Sukabumi regency, those having the habit of consuming fruits were as many as $26.5 \%$ and those having no habit of consuming fruits were as many as $73.5 \%$. Hypertension victims having the habit of consuming vegetables was as many as $60.8 \%$ and having no habit of consuming vegetables was as many as $39.2 \%$.

The number of hypertension victims in Sukabumi regency having a habit of consuming salted fish was as many as $19.6 \%$. Most of the hypertension victims also had a habit of consuming delicious food with flavored seasoning, which is as many as $78.4 \%$, and who had no habit of consuming such things were as many as $21.6 \%$.

The number of hypertension victims in Sukabumi regency who get angry easily (emotional) was as many as $77.5 \%$ and who does not get angry easily (emotional) was as many as $22.5 \%$.

The habit pattern of hypertension victims in Sukabumi regency having the exercise habit of at least once in a week was as many as $14.7 \%$ and having no exercise habit was as many as $85.3 \%$. The pattern habit of hypertension victim in Sukabumi regency having smoking habit was as many as $45.1 \%$ and on the contrary who has non-smoking habit as was many as $54.9 \%$.

Eating vegetables is very important for health, but there are still very few people who actually eat vegetables because they lack enough knowledge about the importance of the nutrients in vegetables. Emitasari, Djarwoto \& Siswati, (2008) stated that for people who seldom consumes vegetables, there's a risk that $1.17 \%$ will get hypertension, and for people who seldom consume fruits, there's a risk that $1.89 \%$ will get hypertension. Sukabumi is more populated by 
Sundanese people and has their own language. Sundanese people like to eat raw vegetables and fruits as fresh vegetables. Raw vegetables and fruits are only cleaned with clean water. Raw vegetables and fruits such as eggplant, petai, cucumber, jengkol, mustard leaves, pohpohan leaves, bunut leaves, reundeu leaves, beluntas leaves, papaya leaves, god yam leaves etc are good for consumption.

Sundanese people like salty food rather than sweet food. Salted fish is their favorite food and salt consumption cannot be controlled. Emitasari, Djarwoto \& Siswati (2008) concluded that the consumption pattern of salted food such as salt, MSG, ketchup, sauce have a $5.76 \%$ risk of getting hypertension. Smoking while drinking coffee has become a daily habit of the young and old alike. Smoking can increase blood pressure even though some researchers have obtained a group of smokers having blood pressure lower than a group of nonsmoker (Mansjoer, 2000). Chemical substance in cigarette such as nicotine and carbon monoxide that came into blood circulation can destroy endothelium surface of blood vessel artery and causes the process of atelectasis and hypertension (Nurchalida, 2003).

\section{CONCLUSION}

The research result shows that, the habit pattern of hypertension victim in Sukabumi regency is caused by culture or habit that does not support healthy life. It is because passing from generation to generation from parent's behavior especially the habit of Sundanese society who consumes salt fish and salt. Sundanese society in Sukabumi regency thinks having rice without salt is not delicious. Sukabumi regency people need positive lifestyle changes, especially about the food they serve, like fast foods that contain preservatives, dyes, chemicals (Monosodium glutamate), and high cholesterol, in order to avoid hypertension.

\section{REFERENCES}

Abate, N. I., Mansour, Y. H., Tuncel, M., Arbique, D., Chavoshan, B., Kizilbash, A., Howell-Stampley, T., Vongpatanasin, W.,Victor,R. G. (2001). Overweight and Sympathetic Activity in Black Americans. Hypertension, pp 379-383.

Dobrian, A. D., Davies, M., Prewitt, R. L. \& Lauterio, T. J. (2000). Development of Hypertension in A Rat Model of Diet-Induced Obesity. Hypertension, 35 (4), pp 1009-1015.

Emitasari, P. D., Djarwoto, B., Siswati, T. (2008). Pola Makan, Rasio Lingkar Pinggangpinggul (RLPP) dan Tekanan Darah di Puskesmas Mergangsan, Yogyakarta. Jurnal Giziklinik Indonesia, 6(2).

Hall, J. E., Hildebrandt, D. A. \& Kuo, J. (2001). Obesity Hypertension: Role of Leptin, and Sympathetic Nervous System. American Journal of Hypertension, 14 (6 pt 2), pp 103S-115S.

Madrigal, L., Brady, J., Raxter, M., Ruiz, E., Otarola, F. \& Blell, M. (2011). Obesity, Hypertension, and Migration: A Meta-Analysis of Populations of the South Asian Diaspora. Human Biology, 83(1), pp 71-86.

Mansjoer Arif, dkk. (2000). Kapita Selekta Kedokteran Edisi 3, Jakarta: EGC

Nurchalida. (2003). Warta Kesehatan Masyarakat. Depkes RI. Jakarta

RISKESDAS (2013).National Institute of Health Research and Development (NIHRD), Ministry of Health (Indonesia) Retrieved from:http://ghdx.healthdata.org/record/indonesia-basic-health-research2013

Soenardi, dan Soetardjo.(2000).Hidangan Sehat Untuk Penderita Hipertensi,Jakarta: Gramedia Pustaka Utama.

WHO.(2010).Global Data Status Report on Noncommunicable Diseases 2010. Retrieved From: http://www.who.int/nmh/publications/ncd_report2 $010 /$ en/ 